\title{
OBSERVATIONS ON THE QUATERNARY GEOLOGY OF AN AREA BETWEEN THE 2ND SALPAUSSELKÄ AND THE ICE-MARGINAL FORMATION OF CENTRAL FINLAND
}

\author{
Reino Repo and Risto Tynni
}

\begin{abstract}
Repo, Reino and Tynni, Risto 1971: Observations on the Quaternary geology of an area between the 2nd Salpausselkä and the ice-marginal formation of central Finland. Bull. Geol. Soc. Finland 43, 185-202.
\end{abstract}

The present study deals with the Quaternary formations and especially with the drumlins in the area between the Salpausselkä system in eastern Finland and the marginal formation of central Finland (Jyväskylä). Early late-glacial sediments from the area have been dated by $\mathrm{C}^{14}$ and pollen analyses.

The Pieksämäki-Juva region is strongly drumlinized. According to seismic refraction data, the average thickness of the till forming a drumlin in Pieksämäki is about 20 meters. The drumlins in Joroinen are mostly low and narrow. According to seismic data, the till is also much thinner, averaging only 7 meters. The drumlins in the study area were formed, according to the authors, at a very late stage of the glaciation in the wide marginal region of a thinning glacier terminating in fairly shallow water. The weak glaciofluvial activity of the glacier could also have been a factor contributing to that formation, although in the final stage, it has been a question of the reactivation of the ice-flow.

The most important of the presented sediment profiles from bogs is the stratigraphic section from the Vuorilampi-pond in Jyväskylä. It is located west of the proximal part of the marginal formation. The $\mathrm{C}^{14}$-age of the oldest dateable sediments from this area was $8130 \pm 160$ B.C. According to pollen statistics, it corresponds to the beginning of the Preboreal or the end of the Younger Dryas period. Due to the possibility of having interglacial organic matter in the sample, the validity of the dating should be accepted with some reservation. It is, however, supported by the $\mathrm{C}^{14}$-dating made by Salmi (1962) from the oldest organic sediments of the Lapaneva bog in Kihniö, west of Jyväskylä.

Reino Repo and Risto Tynni, Geological Survey of Finland, Otaniemi, Finland.

\section{Introduction}

The study area covers the lake-district of SEand central Finland. The largest lakes are Saimaa, $76 \mathrm{~m}$ above sea-level, Puulavesi, about $94 \mathrm{~m}$ and Päijänne, about $78 \mathrm{~m}$ above sea-level. The highest elevations in the area are in the surroundings of Lake Päijänne: Pirttimäki $248.9 \mathrm{~m}$, Tammimäki $242 \mathrm{~m}$, Laajavuori and Ronimäki $227 \mathrm{~m}$ above sea-level. The bedrock in the study area consists of schists and granitic rocks (Frosterus 1903, 


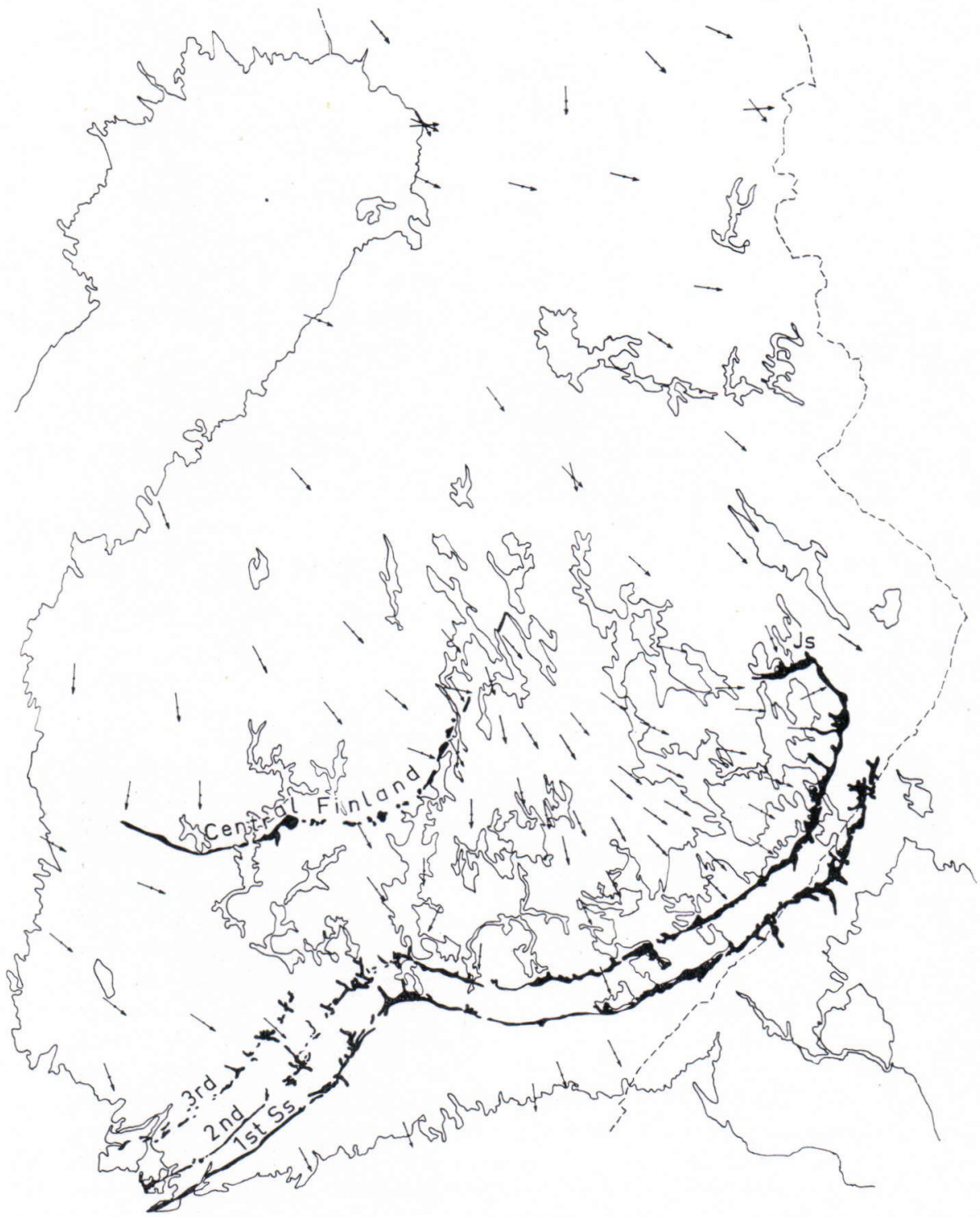

Fig. 1. Major ice-marginal formations (the 1st, 2nd and 3rd Salpausselkäs, Jaamankangs (Js) and the marginal formation of Central Finland) and main striations.

Simonen 1960), exhibiting strong tectonic deformation (e.g. Wegmann 1928). Schistose rocks along the margin of the Svecofennic and Karelian schistbelt and especially farther east in the region of the Karelian orogeny, have a clear NNW-SSE trend. The topography is governed by the main fracture zones, which have been susceptible to erosional processes. The main fracture systems run N-S, NW-SE and SW-NE, although those running NW-SE are the most common (Härme 1961). The influence of the main fracture systems is clearly portrayed on a map in the forms of lakes and river valleys. As early as 1934 Kaikko showed that directional 
erosion induced by fractures in the bedrock was the cause of the three different topographic lineations in Karelia, NW of Lake Ladoga.

The central part of the area in and around the parishes of Juva, Joroinen and Pieksämäki is characterized by a rather thick till bed that commonly forms ridges or drumlins. The bedrock is only occasionally exposed. Drumlins are also typical of the Kuusamo area (Hänninen 1915), but the effect of crustal movements as a catalyzing agent on their formation has evidently been of lesser importance than is probably the case in the formation of eskers. According to Hyyppä (1954), earthquakes have influenced the formation of crevasses in a melting and thinning ice sheet. This opinion is supported by Härme (1961) who has observed that esker chains parallel the major crush zones.

Quaternary formations in central and southeastern Finland have been studied by e.g. Frosterus (1911) in the Mikkeli-Jyväskylä region; as well as by Leiviskä $(1928,1951)$ and Saksela (1930) who have studied the ice-marginal formation of Jyväskylä. A more up-to-date study by Repo (1964) deals with the stratigraphy and dating of the Jyväskylä ice-marginal formation. This marginal formation is associated with the Näsijärvi marginal formation described by Virkkala (1963). Together, these form the central Finnish ice-marginal formation, a glaciofluvial complex that encircled a large lobe in the ice sheet ( $c f$. map, Fig. 1). Although the formation is discontinuous, the section between Jyväskylä and Siikakangas can be easily followed. The best developed deltaic portions are the Halli- and Jämsänkoski-deltas. The formation NE of Jyväskylä is less conspicuous and can be reliably followed to Laukkaa. Sporadic continuations of the system are also found at Vesanto (Fig. 2 and 3) and Pielavesi (Brander 1934). Of the glaciofluvial formations in the southeastern part of the area, the Mikkeliharju has been studied with special emphasis on the material and on the factors contributing to the formation of the esker (Okko 1945). The results of Virkkala's (1952) investi-

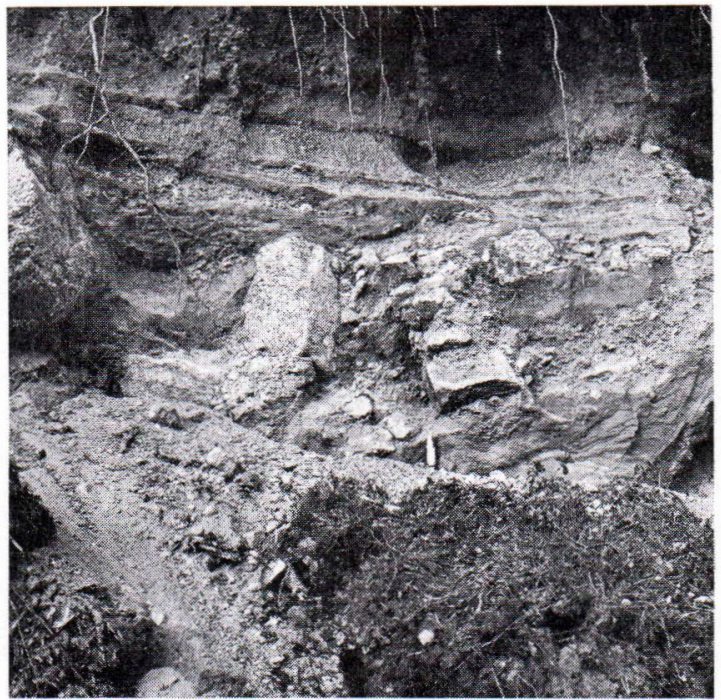

Fig. 2. A vertical section in the proximal part of the marginal formation in the parish of Vesanto. Coarsegrained till in glaciofluvial material.

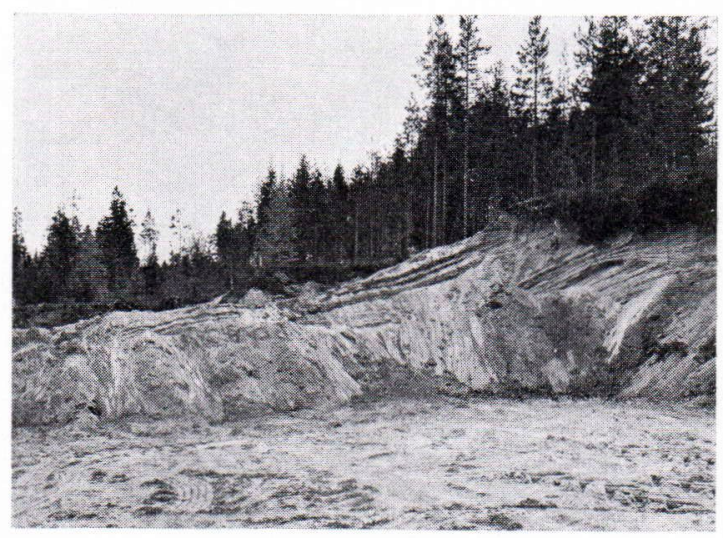

Fig. 3. A vertical section in the distal part of the same formation as in Fig. 2. The material consists of diagonally layered sand and fine sand. The Vesanto formation has been exploited to a large extent.

gations on the structure of till beds in eastern Finland shed some light on the basal tills of the area. Especially Hellaakoski in his studies on the Saimaa (1922) and Puulavesi (1929) lake systems, as well as the works of Lappalainen (1962) and Saarnisto (1970) on the Saimaa lake complex 
elucidate the hydrographic evolution. The latter study deals extensively with the postglacial development of the eastern part of the present study area. The postglacial evolution of the western part is dealt with in a study on the Päijänne region by Aario (1965). Postglacial vegetation conditions have been treated by Valovirta (1962) in a study on the Cladium niariscus occurrence in Joroinen. There is a description by Jalas and Okko (1951) from the same locality.

The purpose of the present study is to elucidate some late- and early postglacial events in the development of the area. It is a continuation of a study of the late- and postglacial evolution of an area farther SE, along the line of the retreating continental ice sheet (Repo \& Tynni 1967, 1969). The use of the $\mathrm{C}^{14}$-dating of phytogenic sediments for determining the minimum age of the retreat of the ice sheet will probably give better results in the present area than in those areas where the retreat took place at an earlier stage during more arctic climatic conditions. In the latter case, the vegetation was slower at gaining a foothold and thus sediments formed in the proximity of the retreating ice front rarely contain organic matter. The oldest sediments containing organic matter will only give the minimum age for the retreat. More exact dating can be achieved by also using varve chronological data. This type of work was done by Prof. M. Sauramo, using however rather primitive methods. According to him, the ice sheet retreated from the 2nd Salpausselkä during the draining of the Baltic ice lake at Billingen. According to Nilsson (1968), this happened in 8213 B.C. Also Donner (1969) confines the drainage to the 2nd Salpausselkä, but Hyyppä (1963) associates this event with the retreat of the ice-margin from the 3rd Salpausselkä. According to Sauramo, it took 200 years for the ice to retreat from the 2 nd Salpausselkä to the 3rd Salpausselkä. Thus, according to Hyyppä, the ice would have retreated from the 2nd Salpausselkä in 8413 B.C.. Mölder, Valovirta and Virkkala (1957) have dated this event at an even earlier stage.

\section{Drumlins}

Drumlins are typical formations of the glaciated regions of North America and northern Europe. They generally occur in groups or in fields, their greatest spread being parallel to the edge of the ice sheet. At this point it is worth while mentioning, from the large amount of literature dealing with drumlins, the extensive summary of Ebers (1926). In Finland, drumlins are common in several regions within the 2 nd Salpausselkä, but are extremely rare beyond the Salpausselkä end moraines.

The most numerous drumlin occurrences in the study area are found in the regions of Pieksämäki, Joroinen, Juva (Frosterus 1913) and Kuusamo (Hänninen 1915). Till ridges 10-15 meters high, rarely exceeding $1-2$ kilometers in length and having the same direction as the ice movement have already been described from central Finland by Sederholm (1889).

Drumlins are also typical of the region south and west of Keitele where they attain a length of several kilometers and 200-300 meters in width (Brander 1934). According to Brander, material in a drumlin is coarser at the proximal end than in the distal part. The bedrock often reaches the top of the drumlin. In his description of the Kajaani map sheet, Sauramo (1926) mentions occurrences of drumlins NE of Runni in particular, in the vicinity of the watershed between Vieremä, Vuolijoki and Murtomäki, as well as at Tavastkenkä in Pyhäntä, in the village of Piippola, in Pulkkila and in Kestilä. Virkkala has mentioned occurrences of drumlins from several map sheet areas in eastern Finland (Virkkala 1949, 1960) and also some from the vicinity of Hämeenlinna at Renko (Virkkala 1969). A distinct drumlin group has been described from the Koijärvi-Urjala region (Aartolahti 1966, 1968). Drumlins in Ostrobothnia are partially covered by clays (Okko 1949). Mölder and Salmi (1954) have described a special type of drumlin consisting of longitudinal ridges interconnected by transverse ridges forming a regiculated topography. This type of formation is probably com- 
parable with the superposition of end moraines and radial moraines as in Korso in southern Finland (Virkkala 1959). Similar accumulation forms of boulder clay in addition to regular drumlins are also found elsewhere in southern Finland and in Lapland (Tanner 1915, Kujansuu 1967). They seem to some extent to resemble the socalled Rogen moraine and drumlin landscape of Jämtland in western Sweden described by Magnusson, Granlund and Lundqvist (1949), Hoppe (1952) and most recently by J. Lundqvist (1969). These transverse ridges, made up of crescentic portions, convex in the direction of the ice-movement, were formed subglacially in topographic depressions. They occasionally exhibit features that make them transitionary to drumlins. However, regular drumlins are found in quite different topographic conditions, generally in elevated localities.

An example of a drumlin formed from sorted material (according to surface observations) is the island of Ramsholm in Åland (Jaatinen 1952).

\section{Drumlin regions of central and southeastern Finland}

The drumlins of the study area (map, Fig. 4) can be morphologically separated into three different types. The first type consists of distinct straight ridges, 1 to $2 \mathrm{~km}$ in length, 200 to $300 \mathrm{~m}$ in width and 20 to $30 \mathrm{~m}$ in height. The highest part is located either at the center or somewhat towards the proximal end. A typical drumlin of this type is found near the town of Pieksämäki on the western side of lake Naarajärvi. It is located between the lake and a bog basin. Although the area is topographically fairly flat, with the exception of the numerous lakes and bog basins, it has been rather strongly drumlinized. These drumlins are not concentrated in any marked way on the proximal sides of basins as is the case in western Sweden (Gillberg 1955, Hillefors 1969). Many of the basins, especially the bog basins, give the impression of being so-called negative drumlins (Woldstedt 1954). The Pieksämäki drumlin consists as do the local tills in general, at least near the surface, of a sandy basal-type till (Fig. 5). According to seismic refraction data, the average thickness of the till deposit is 20 meters and reaches a maximum value of 35 meters. The bedrock level comes nearest to the surface in the proximal part of the formation (Fig. 6). The thickness of the till cover in this case is of such a magnitude that the topographic ridges can mostly be attributed to the deposition of till into the drumlins. The influence of the bedrock on the topographic features seems to have no major significance. This can also be deduced from the fact that outcrops are lacking in the vicinity.

The second type of drumlin is found in the relatively flat lake district and is considerably lower, narrower and longer than the previous one. Drumlins of this type are often 2 to $3 \mathrm{~km}$ long, occasionally even longer, 100 to $200 \mathrm{~m}$ wide and $10 \mathrm{~m}$ or less in height. Seismic refraction studies in the southern part of Joroinen gave an average thickness of $7 \mathrm{~m}$ for the till of this type (Fig. 7 and 8). The lateral distance between the narrow drumlins in the Joroinen region varied from 200 to 400 meters but was mostly $200 \mathrm{~m}$. Due to its narrow and outstreched appearance, this type resembles the forms in the drumlin and small-scale flutings landscape of Enontekiö described by Kujansuu (1967). Compared to the Pieksämäki drumlin, the material near the surface of the drumlins in Joroinen is more fine grained sandy to fine sandy till. Also in this case, the material is somewhat coarser in the proximal part than elsewhere.

The third type is characterized by an almost egg-shaped or rounded triangular plan form, with the blunt end representing the proximal part of the drumlin. A drumlin of this type is located at Vuorenmaa in Juva. It is a hill with a summit height of $181.5 \mathrm{~m}$ while the lowest part on the distal side is $135 \mathrm{~m}$ above sea level. It is $3 \mathrm{~km}$ long and $700 \mathrm{~m}$ wide (Fig. 9). At the summit, the bedrock lies 4 meters below the surface (Tuhkainmäki well), but there is a small outcrop on the side slope. Similar formations 


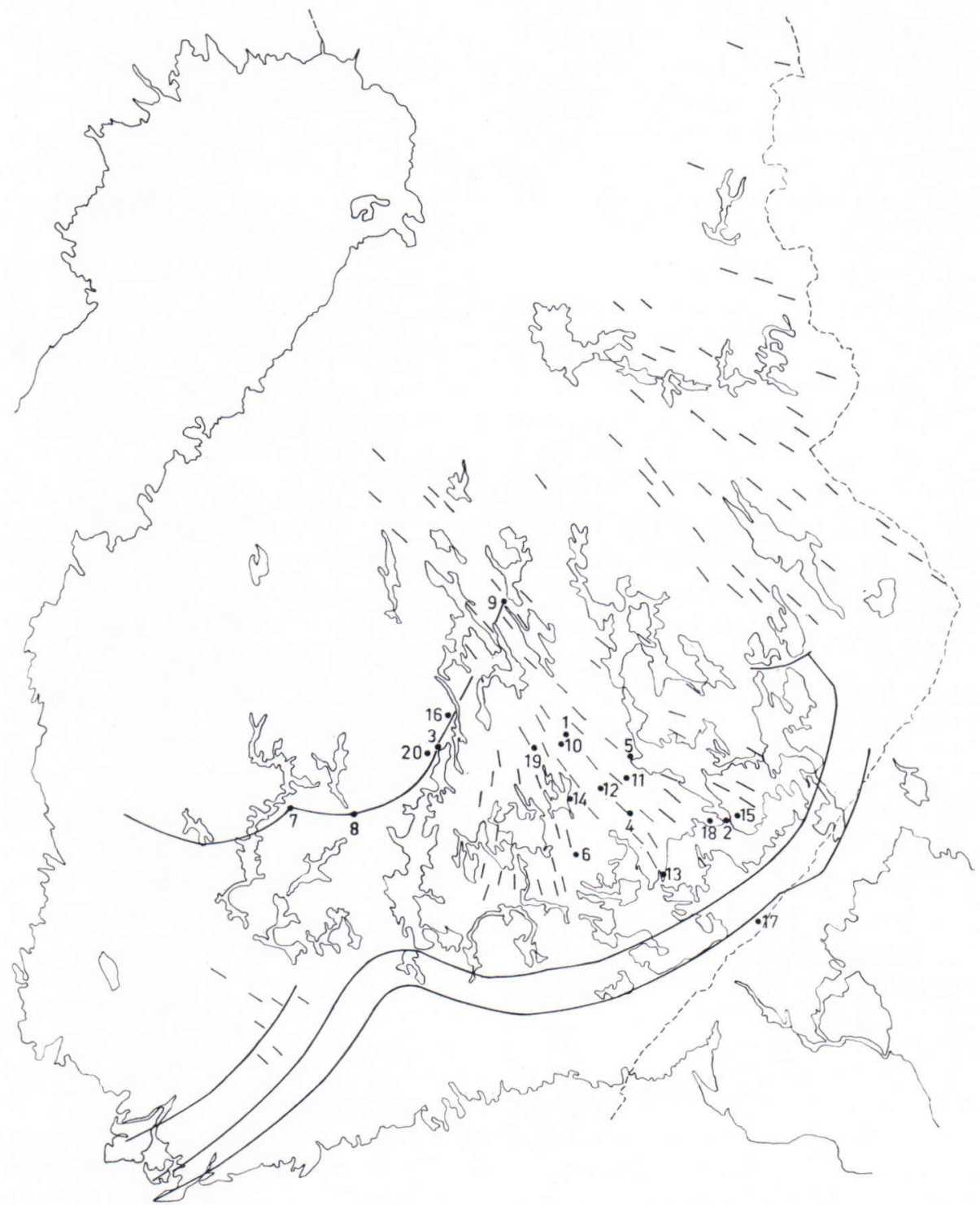

Fig. 4. The location of some drumlin occurrences. The lines represent the general orientation of the drumlins. - Observation points: 1. Pieksämäki 2. Savonlinna 3. Jyväskylä 4. Juva 5. Joroinen 6. Mikkeli 7. Siikakangas 8. Halli 9. Vesanto 10. Tuomaankangas 11. Lenninselänne 12. Vuorimaa 13. Puumala 14. Haukivuori 15. Nojanmaa 16. Majajärvi, Leppävesi 17. Pikku-Miettilä 18. Korkiasuo 19. Mäkilampi 20. Vuorilampi.

are found near Savonlinna, e.g. the hill of Sippurinmäki, which is, however, smaller in size. It is evident that in this last type, the bedrock reaches closer to the surface than in the other types and they are best associated with rock drumlins (Fig. 10). Drumlins of this type are often overlapped by smaller »embryonic» drumlins and are generally found to occur sporadically as single forms.

Early investigators described the drumlins as having been formed subglacially as till ridges piled up around a bedrock nucleus. The for- 

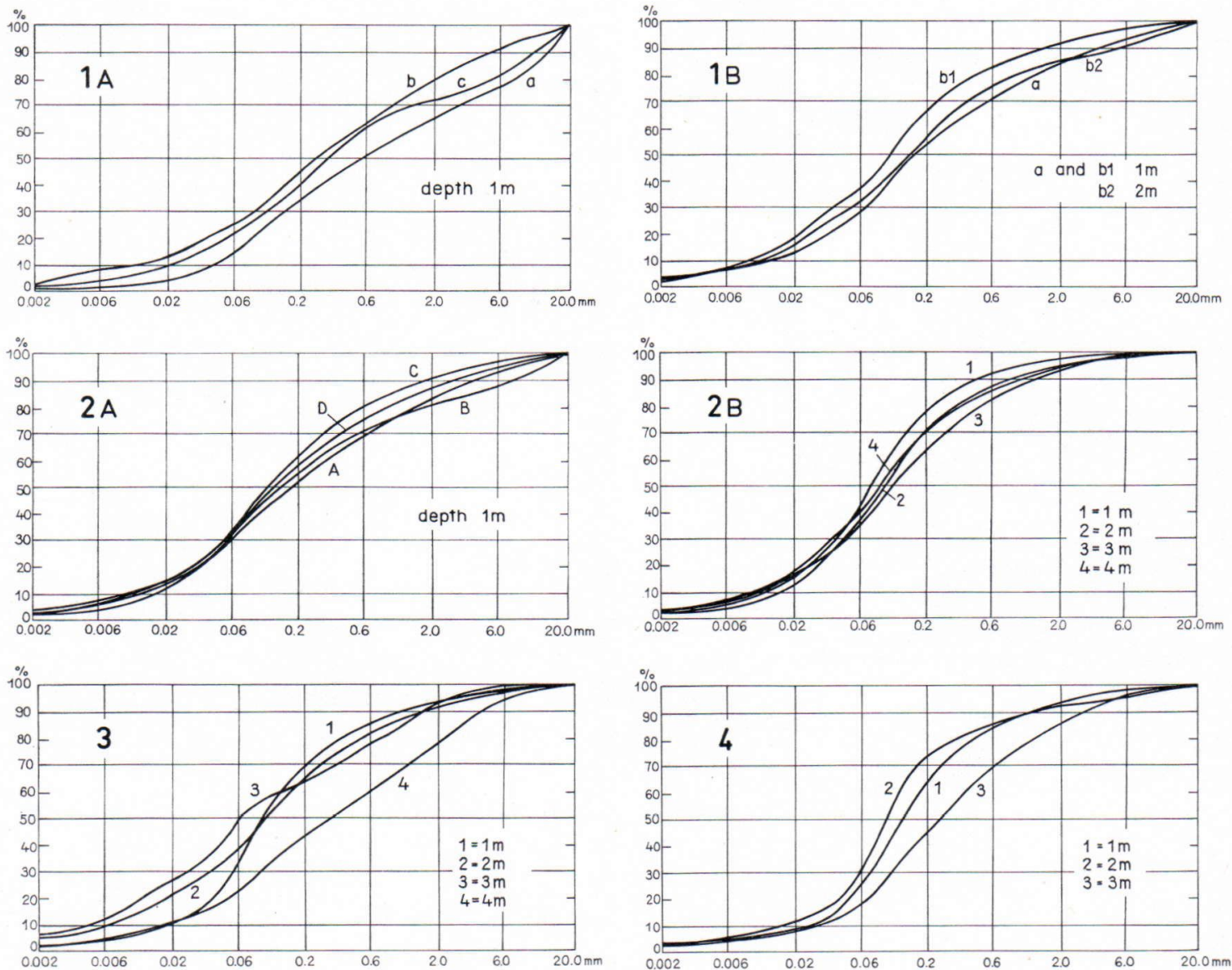

Fig. 5. 1 A. Drumlin, Tuomaankangas, Naarajärvi. a) proximal part, b) summit, c) distal part. 1 B. A nearby drumlin, Korkeakangas, a) proximal part, b) summit, 2 A. Drumlin, Lenninselänne, Joroinen. Sample locations A, B, C, D are shown in Fig. 8. 2 B. Drumlin, Kankanpelto, $3 \mathrm{~km} \mathrm{~S}$ of the above. Section in the central part. 3. Distal part of drumlin, Simpalanmäki, NNE of Savonlinna. 4. The till bed at Nojanmaa.

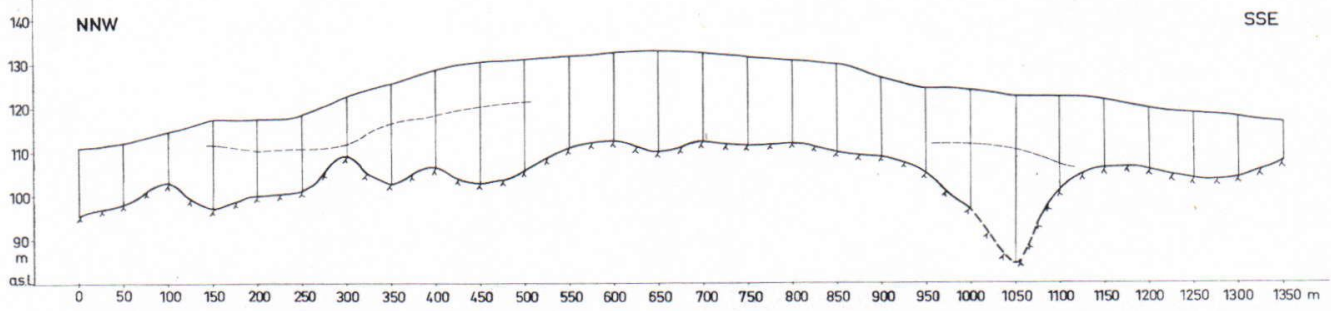

Fig. 6. A longitudinal profile of the drumlin at Tuomaankangas. The bedrock level, height of ground water table (dashed line) and the thickness of the till deposit were determined by seismic refraction.

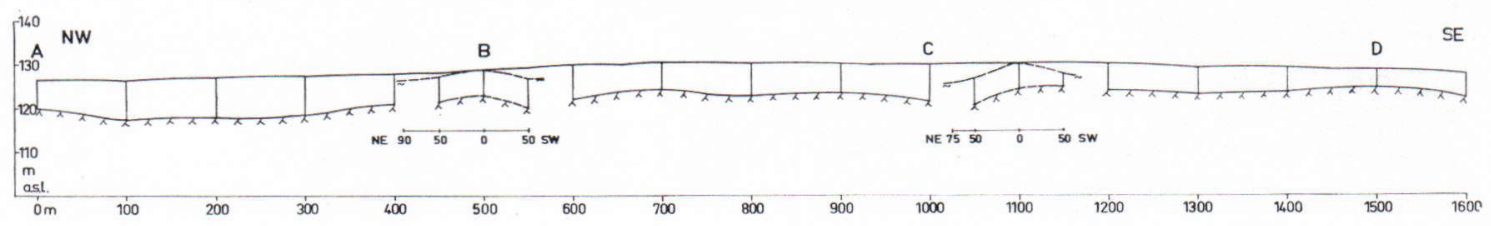

Fig. 7. A longitudinal profile and two transverse profiles (dashed line) across the Lenninselänne drumlin. 


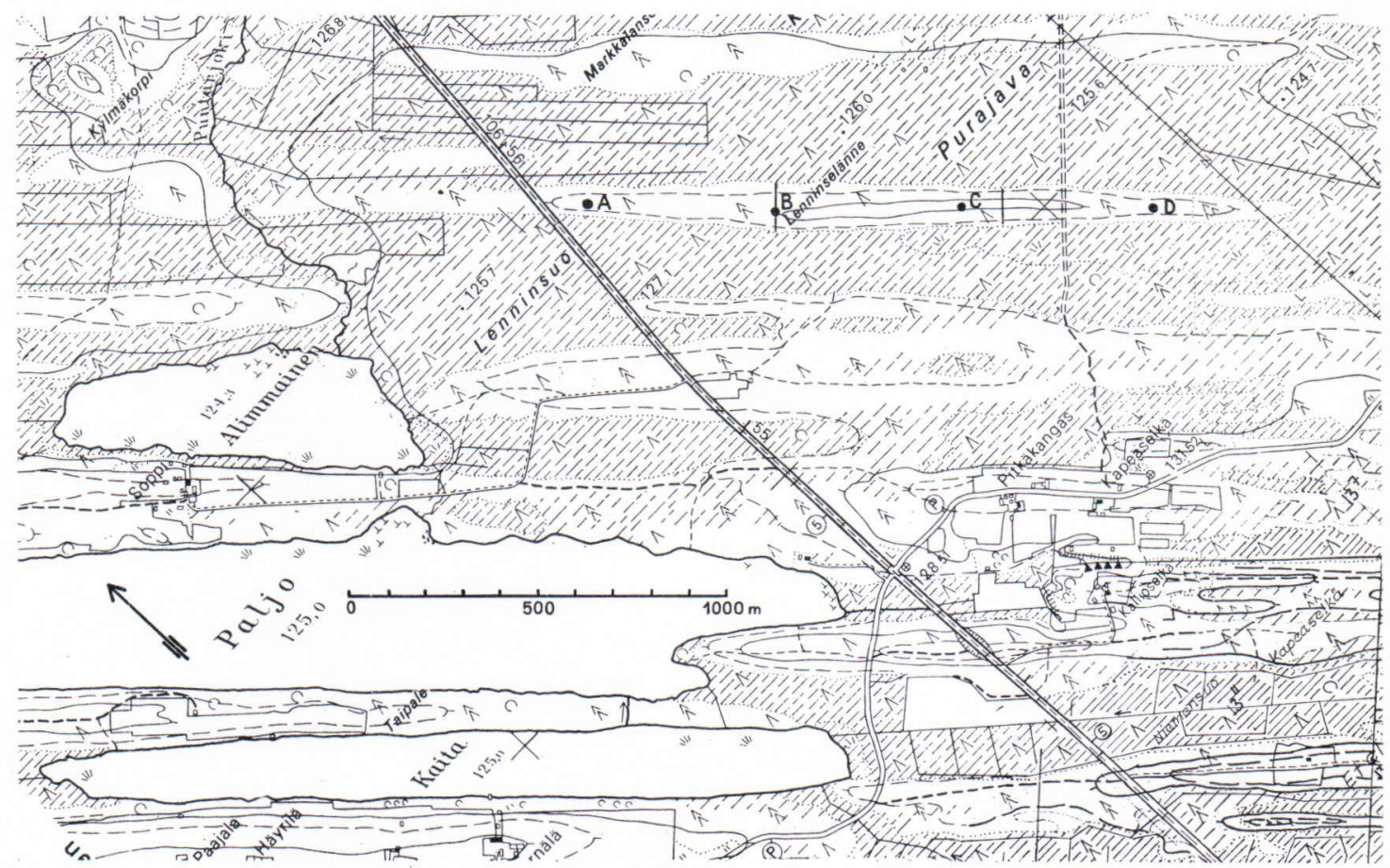

Fig. 8. The drumlin region of Lenninselänne. Part of the General Survey Office topographical map No. 323303 A.

mation was initiated when till accumulated at the bottom of the glacier and started to concentrate against even a small bedrock hump. When the lower part of the glacier became heavily loaded with till, it stagnated, whilst the higher plastic layers of the glacier continued to glide over, continuously accumulating till. Thus, con- siderable amounts of till could be accumulated on top of the original bedrock hump (Russel 1895, Flint 1949).

Smalley und Unwin (1968) have conducted experimental research on the formation of drumlins. According to them, drumlins can form only under specific pressure conditions. When the

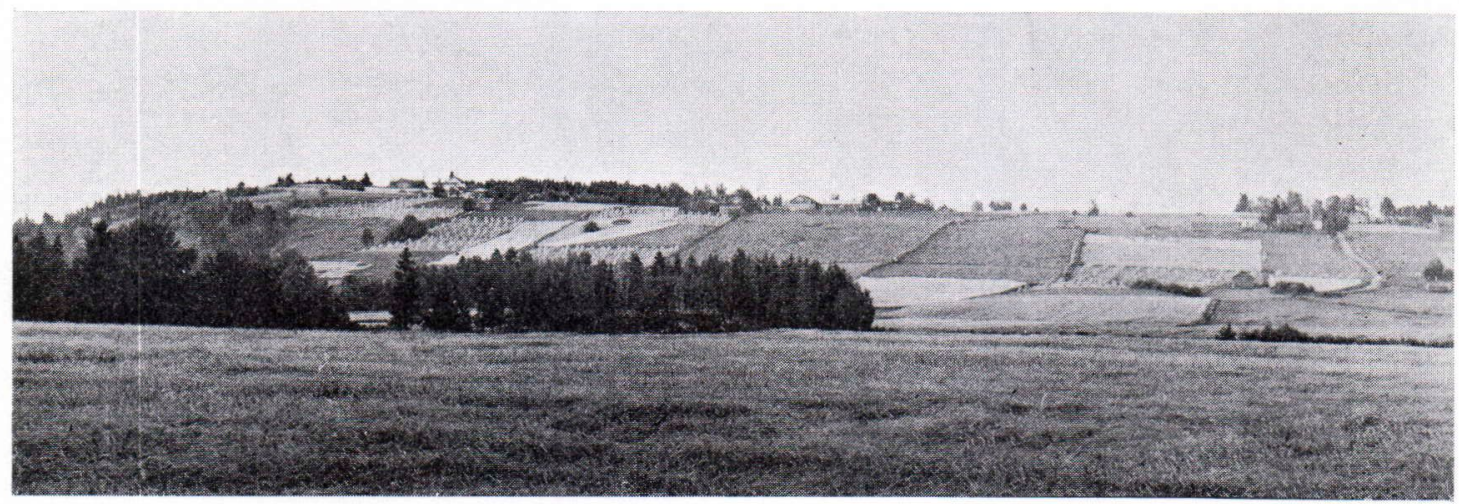

Fig. 9. The proximal part of the drumlin at Vuorimaa rising 40 to 60 meters above the surroundings. Western Juva. 


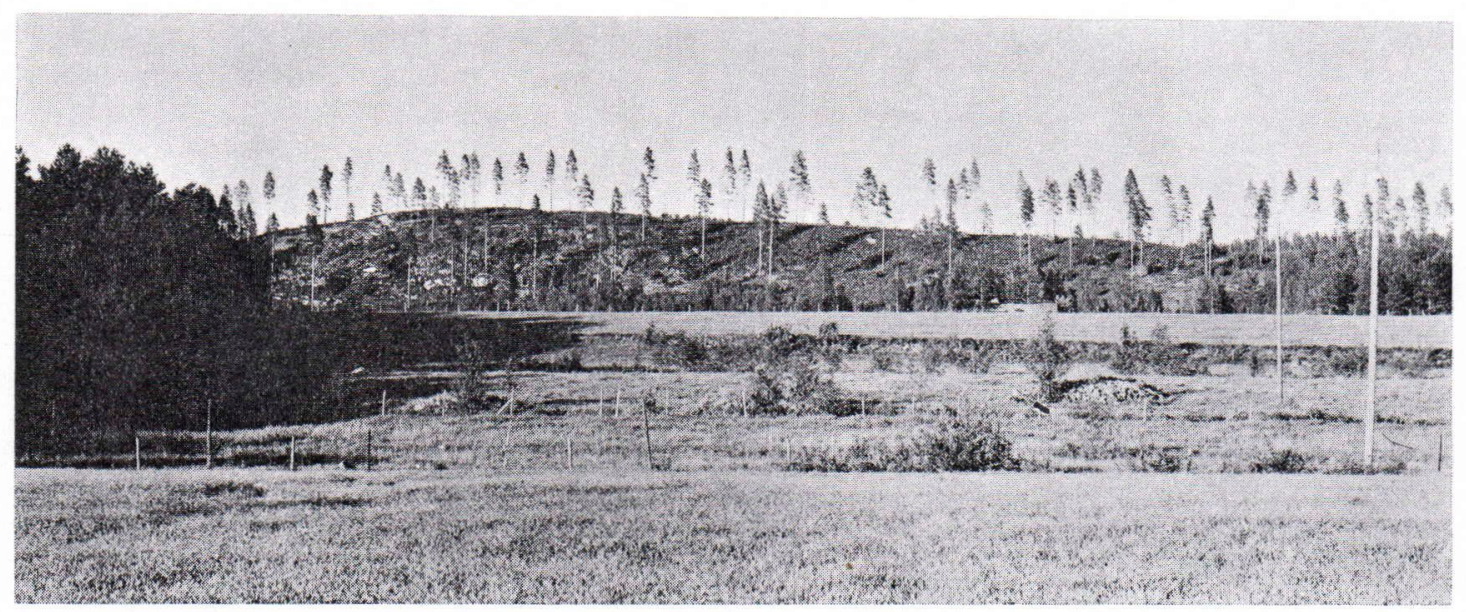

Fig. 10. The drumlin Kainulaisenkenkku, in the parish of Puumala. The proximal part is outcroping rock.

granular material in basal till is stressed over a specific limit, it first causes expansion in the packing which is followed by a collapse causing the material to be picked up by the flowing ice sheet. When the stress level drops sufficiently, the granular material again aquires a static and stable state, often in the form of a drumlin. Especially tills containing large rocks and boulders are susceptible to this process leading to the formation of drumlins, provided that suitable pressures are operative. Such pressure conditions exist below the marginal parts of ice sheets.

Considering the occurrences of drumlins in Wisconsin, it has been proposed that a relationship exists between the formation of drumlins and a relatively thin ice sheet (Alden 1918, Flint 1949). The formation of crevasses in the marginal part of the ice sheet is quite possible in this type of glacier, thus possibly aiding the accumulation of mineral matter much in the same way as Hoppe (1948) proposed for the formation of marginal moraines. This can, of course, be best applied to the radial moraines of the marginal zone of a glacier. This type is probably represented by the short drumlins from the Heinola region described by Fogelberg (1970). The drumlins located east of Heinola and $10 \mathrm{~km}$ north of the 2nd Salpausselkä have a direction perpendicular to the Salpausselkä and parallel to the direction of the icemovement at the time of the formation of the 2nd Salpausselkä. The older ice-flow differs considerably from this direction. Also Hoppe (1951) assumes that the drumlins in Norrbotten in northern Sweden were formed during the time of glacial retreat. These drumlins occur above the highest marine line and exhibit the same direction as the last ice-movement. The same direction is found in the orientation of the till stones.

The orientation of the drumlins in the study area corresponds to the youngest ice-movement. It is evident that the drumlins, especially the long and narrow ones, would hardly have preserved their ridge-like forms if overridden by an ice sheet from a different direction. Exceptions to this have, however, been described in literature. In the regions of Pieksämäki, Juva and Joroinen the drumlins all have the same direction regardless of the many lake basins, which indicates that the direction of flow of the ice sheet was not influenced by the local, relatively low-relief topography at the time of the formation of the drumlins. In the Jyväskylä and Haukivuori regions, where the local topography is more rugged, the orientation of the drumlins is more varied. 


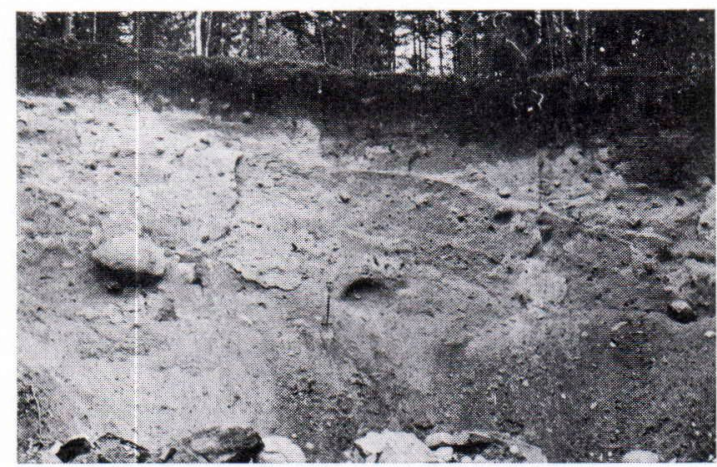

Fig. 11. Section of the drumlin Kankaanpelto (cf. Fig. 5. 2 B.). The till exhibits a weak stratification sloping gently towards the distal part.

The theory that drumlins were formed in longitudinal crevasses in the glacier has been presented by Chamberlain (1894) and Alden (1905). In the cases where glaciofluvial deposits have been drumlinized (e.g. Leiviskä 1928, Virkkala 1960, Jaatinen 1952) this could have been true, but it does imply a reactivation of the glacier.

The drumlins in the Pieksämäki-Juva region were probably formed as the result of the varied accumulative and erosive activities of the glacier. The till-like fabric indicates accumulation by a plastic ice-flow (Fig. 11). The somewhat sorted material, as compared to a typical basal till, might indicate that the material was partly accumulated through subglacial crevasses from water-transported washed-out till. Selective erosion and deposition of till by a plastic ice-flow could lead to the same result. The relatively thick till beds of the Pieksämäki-Juva region indicate either the existence of concentrations of preWeichselian glacial material, or more probably the considerable accumulation of till material during the final stages of the last glaciation. Suitable environmental conditions could have been induced by the thin but vast marginal zone of the glacier retreating through relatively shallow water and occasionally oscillating back and forth. A glacier of this type could contain an abundance of crevasses and tunnels which could cause the hydrostatic pressure to be lower than in areas where abundant glaciofluvial deposits and correspondingly also varved clays were formed. The latter is a function of sufficient hydrostatic pressure and water flow. Crevasse and tunnel systems trending NW-SE could have formed in the thinning glacier due to crustal uplift movements and guided by bedrock tectonics (cf. Hyyppä 1954). Finally, due to the activation and flow of the glacier, previously accumulated material was formed and oriented into drumlins.

The activation of the glacier could have occurred during the climatic deterioration during the transition between the Younger Dryas and the Preboreal periods from $8100-7700$ B.C. (Zoller 1960, Behre 1967; Piottino-oscillation, $c f$. Repo \& Tynni 1969) or even earlier during the transition between the Alleröd and the Younger Dryas periods. The large ridge-like formation of Nojanmaa near Savonlinna, one section of which shows variations from glaciofluvial material to till, supports the possibility of reactivation.

Drumlins remain intact during the melting phase of the ice sheet, provided that the ice is not active during the retreat of the ice margin and that the ice melts in a stagnant state. This is indicated by the lack of drumlins or their deformation e.g. in the areas of the Irish marginal moraines (Sygne 1952). There are no welldeveloped drumlins in Finland along the Salpausselkä zone where the ice margin was active. On the other hand, marginal moraines are known to occur on top of drumlins e.g. in the New York region (Fairchild 1907), but these cases are rare.

The previously mentioned large sand and gravel section in the formation of Nojanmaa near Savonlinna contains occasional till beds which are several meters in thickness and overlie glaciofluvial sediments (Fig. 12). The height of the section varies from 12 to 25 meters. Also short rock drumlins are found in the nearby areas. The burying of glaciofluvial material under a cover of till suggests climatic changes during the final stages of the glaciation. They have caused considerable melting, reactivation of the glacier and oscillation of the ice front. 


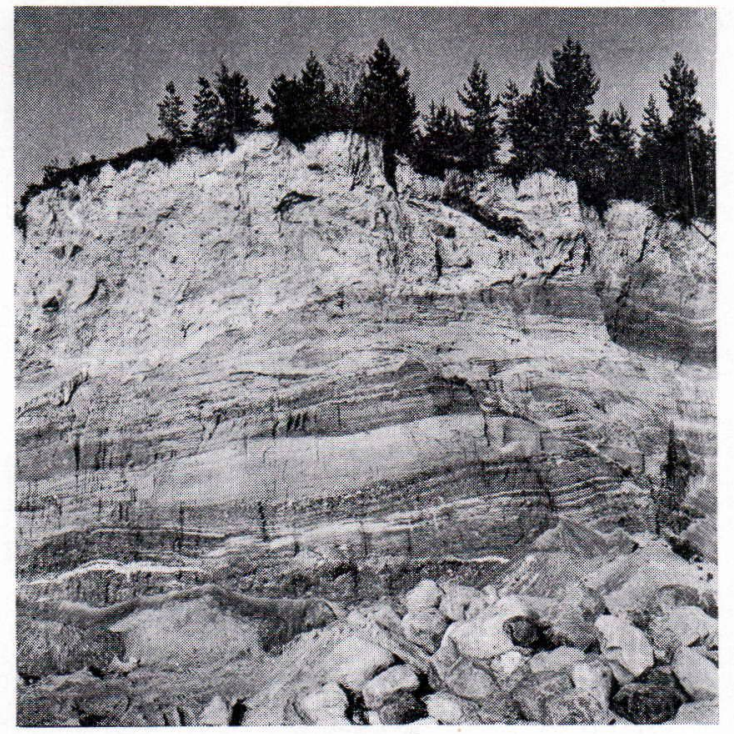

Fig. 12. Section through the ridge-like formation at Nojanmaa. The top 6 meters consists of a till bed overlying stratified sand and gravel. The light coloured lenses are silt.

(cf.: involutions in the superficial deposit in the marginal formation of Jyväskylä, Fig. 13).

Drumlins are also found in the region between the 2nd Salpausselkä and the central Finnish ice-

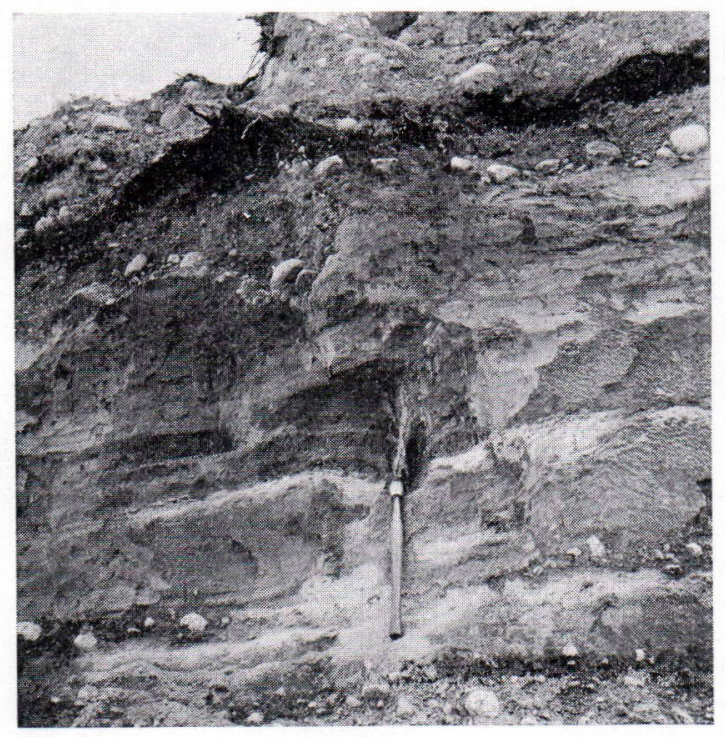

Fig 13a. A vertical section in the marginal formation of Jyväskylä in Leppävesi E of Majajärvi. Distortion of the upper glaciofluvial strata is the result of frost effects. marginal formation, from where the ice margin retreated evidently due to considerable climatic changes during the Younger Dryas and the beginning of the Preboreal periods. The majority of the East Karelian (USSR) drumlins (Apuhtin and Krasnoff 1967) are located in a topographically similar lake region.

\section{Early postglacial development according to pollen and diatom analyses}

It is generally accepted that the ice margin retreated from the 2nd Salpausselkä at the time of transition from the Younger Dryas to the Preboreal period. This phase corresponds to climatic amelioration and the lowering of the Baltic waters by $27-28$ meters (B III). According to Sauramo (1958), this was followed by three short-termed ice-lake stages. Hyyppä (1963), M. Okko (1965) and Donner (1969) show, however, that these stages never existed. In accordance with the general climatic evolution, the climatic amelioration during the end of the Younger Dryas and the beginning of the Preboreal was followed by the so-called Piottino

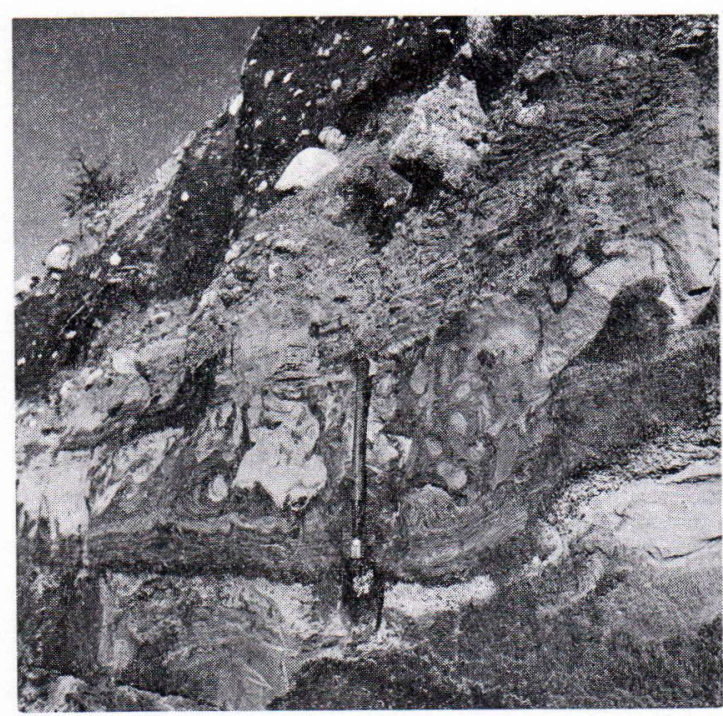

Fig. 13b. A folded layer of fine sand between coarser strata at a depth of 1.5 meters, in close proximity to the location of Fig. 13a. 
oscillation. Naturally, it also led to a readvance of the Fennoscandian ice sheet. The possibility of its extending to Billingen and causing a new Baltic ice-lake stage will not be discussed here. Its influence is noticeable, e.g. as a decrease in the organic content of sediment profiles from the pond of Sippurilampi in Koivusilta and a bog (Lempinlampi) near Eräjärvi (Repo and Tynni 1969). The correlation of this stage with shore line displacement is still unsolved. A sedimentary section from a bog near Eräjärvi, on the proximal side of the 2nd Salpausselkä, dating from the end of the Younger Dryas period or the beginning of the Flandrian period, clearly shows a climatic deterioration. Since tills are lacking in the section, there is no proof that the ice-margin would have advanced to the 2nd Salpausselkä. It is possible that the ice-margin had a position corresponding to the 3rd Salpausselkä stage. The 3rd Salpausselkä itself is missing in the area and is to be found well-developed only in western Finland.

The sediment cores, used here to elucidate the retreat of the ice-margin from the 2 nd Salpausselkä to central Finland, were collected from Sääminki, Pieksämäki and the Jyväskylä area. The highest shore line in the region was formed by the ice-lake of southern Saimaa and by Yoldia I (Hellaakoski 1922, 1928). Farther north, in the Kuopio area, Donner has defined the elevation of Y II at 147 meters. A great part of the area belongs to the Ancient Saimaa region. According to Saarnisto (1970), the elevation of the Ancient Saimaa in this area was 82-104 meters. The elevated areas in central Finland and also partly in southeastern Finland were topographically suitable for the early formation of organic water sediments immediately after the retreat of the ice-margin. Due to the proximity of the glacier, the sediments deposited in the small lakes were very rich in mineral matter. The organic component consists primarily of the remnants of Bryales-moss and often of detritus of undefineable origin. The diatom flora in this type of material has mostly been deposited from contemporaneous dust rains (Tynni1970). The secondary interglacial pollen is generally associated with the bottom varves of the clay sediments. The sedimentary sequence described from the Mustalampi bog in Ilomantsi on the distal side of the 1st Salpausselkä (Repo and Tynni 1967) is an example of the beginning of organic sedimentation at the end of the Younger Dryas period in southeastern Finland. It was dated by $\mathrm{C}^{14}$-analysis at $8110 \pm$ 140 B. C.. It corresponds both in time and locality to the $\mathrm{C}^{14}$-dating of $8190 \pm 225 \mathrm{~B}$. C. presented by Tolonen (1967) from the Mutalahti bog in Ilomantsi. The $\mathrm{C}^{14}$-age of the oldest organic sediment taken from the Koivusilta bog in the parish of Saari, between the 1st and 2 nd Salpausselkäs, was 8250 B. C.. The organic layer was covered by silt sediments which have been interpreted by the present authors as indicating climatic deterioration following the retreat of the ice-margin and comparable to the Piottino dating of a small bog near Eräjärvi on the proximal side of the 2 nd Salpausselkä gave a result of $8150 \pm 400$ B. C.. Even here, the sediments of $8150 \pm 400$ B. C.. Even here, the sediments showed signs of a climatic fluctuation similar to that at Koivusuo (Repo and Tynni 1969). According to the pollen diagram for the sediment core from Pikku-Miettilä in Rautjärvi, south of the 1st Salpausselkä, the bottom sediments containing organic material were deposited during the final phase of the Younger Dryas period. Fig. 14 shows a new pollen diagram made from this section of the core and also the $\mathrm{C}^{14}$ date for the sediment. (The radiocarbon determinations were made by Isotopes Inc., New Jersey). The age of $8080 \pm 160$ B. C. $(10.030 \pm$ 160 B. P.) is practically the same as for the sediments from Koivusilta and Eräjärvi (Lempilampi). Also in the core from Pikku-Miettilä the organic sediment is followed by a $4.5 \mathrm{~cm}$ thick layer of inorganic material. Thus, the same phenomenon has been observed in four sediment cores from southeastern Finland. The elevation of the localities varies as follows: PikkuMiettilä 117 meters, Koivusilta 128 meters, Sip- 


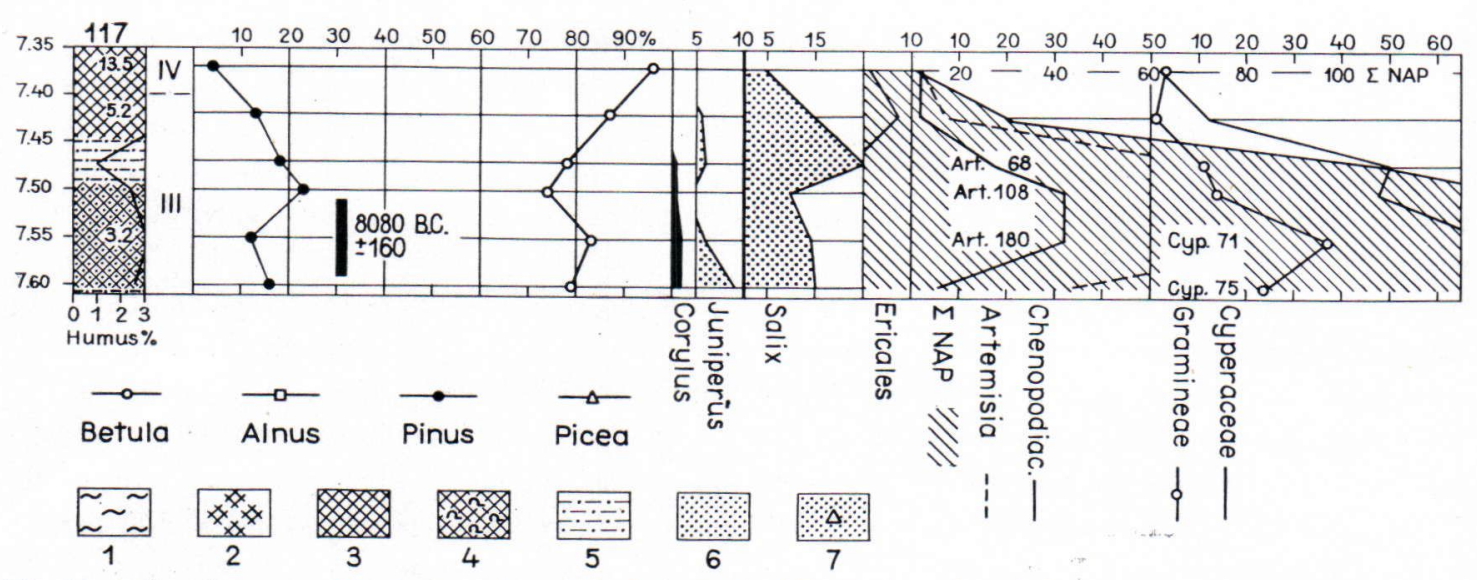

Fig. 14. Pollen diagram of the bottom deposits of the Pikku-Miettilä bog. $1=$ Sphagnum-peat, $2=$ mud, $3=$ gyttja, $4=$ Bryales-gyttja, $5=$ silt, $6=$ fine sand, $7=$ fine sand and till-like material.

purilampi 118 meters and Eräjärvi 125 meters. Since the intermediary inorganic sediment layer from Pikku-Miettilä contais the largest amounts of clay and is located at the lowest elevation, the formation of the inorganic sediment can probably be associated with the water level fluctuations of a rather large body of water. The diatoms from the oldest organic sediments of PikkuMiettilä consist of both large and small water forms.
The sediment core of Korkiasuo was taken from an area that rises above the surrounding terrain in the parish of Sääminki, about 40 kilometers NW of the proximal part of the 2nd Salpausselkä. The bottom sediments from the bog located 142 meters above sea level were formed during the Preboreal period (Fig. 15) according to the pollen diagram. On the basis of the $\mathrm{C}^{14}$ dating the deposition of the organic sediment began at about 7560 B. C. $(9510 \pm 160$ B. P.).

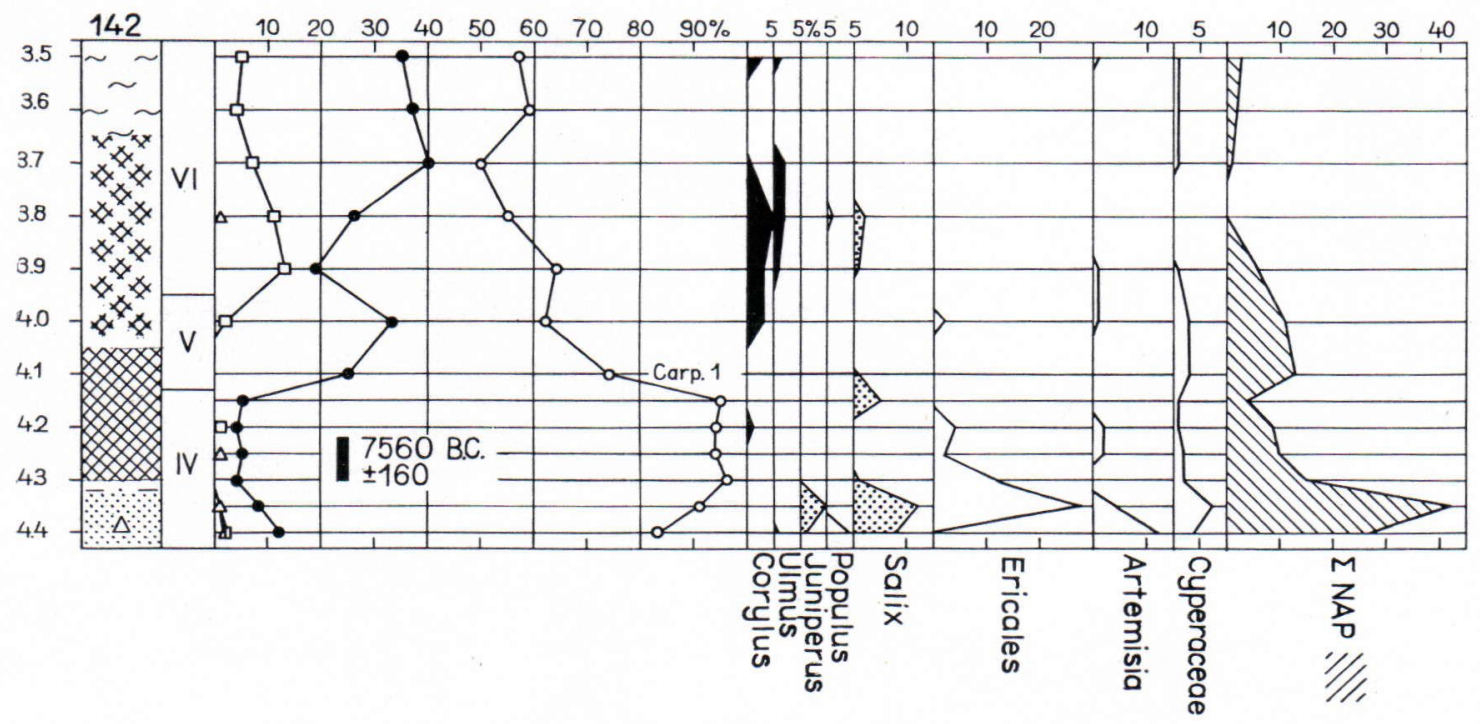

Fig. 15. Pollen diagram of the Korkiasuo bog. Same legend as in Fig. 14. 
The diatom flora in the sediment consists predominantly of small water forms, the majority being the small fresh water forms Pinnularia interrupta, Fragilaria construens, and Cymbella naviculiformis. Forms typical of larger bodies of water and of the Yoldia Sea are missing; according to Sauramo (1958), the Yoldia Sea never attained this elevation. The area could have developed into a small lake bordered by vegetation rather soon after deglaciation.

The pond of Mäkilampi, at about 154.5 meters above sea level, is located approximately 20 kilometers SW of the town of Pieksämäki. The same features as at Korkiasuo are visible in the sediment core taken from the southern shore (Fig. 16). According to $\mathrm{C}^{14}$-dating, the deposition of the early gyttja-clays began here at about the same time as in the previous location. The $\mathrm{C}^{14}$ age of 7480 B. C. (9430 \pm 160 B. P.) corresponds to the Preboreal climatic amelioration. The diatom succession in the sediments is typical of small lake stages. Only the oldest sample contained $2 \%$ of the species Amphora obscura, typical of arctic brackish and fresh waters.

The sediment profile in Fig. 17 shows the lower part of a core taken from the bog on the shore of Vuorilampi at an altitude of 181 meters above sea level in the proximity of Ronimäki (Ronninmäki), $226.5 \mathrm{~m}$ a.s.b., one of the highest spots on the proximal side of the Jyväskylä glaciofluvial marginal formation in the (Sauramo 1929, Repo 1964) Jyväskylä region. This sediment profile is peculiar in two respects. The $\mathrm{C}^{14}$-dating of the oldest organic sediment, gave the extraordinarily high age of 8130 B. C. $(10.080 \pm 160$ B. P.), comparable with the dates from the Salpausselkä region. If the age, even within the limits of the standard deviation of $160 \mathrm{yrs}$, is correct it would imply a surprisingly early date for the deglaciation of the region. It would also be contradictory to several earlier investigations (e.g. Sauramo 1958, Donner 1969). It does, however, agree with the results of Mölder, Valovirta and Virkkala (1957) and it is fairly close to the deglaciation schedule presented by Hyyppä (1963). According to Mölder, Valovirta and Virkkala, the ice-margin had retreated to the Tampere area already during the Dryas period. This would have occurred rapidly due to calving at the ice-margin along the Näsijärvi basin. This conclusion is based to a large extent on the interpretation of the pollen flora in the bottom sedi-

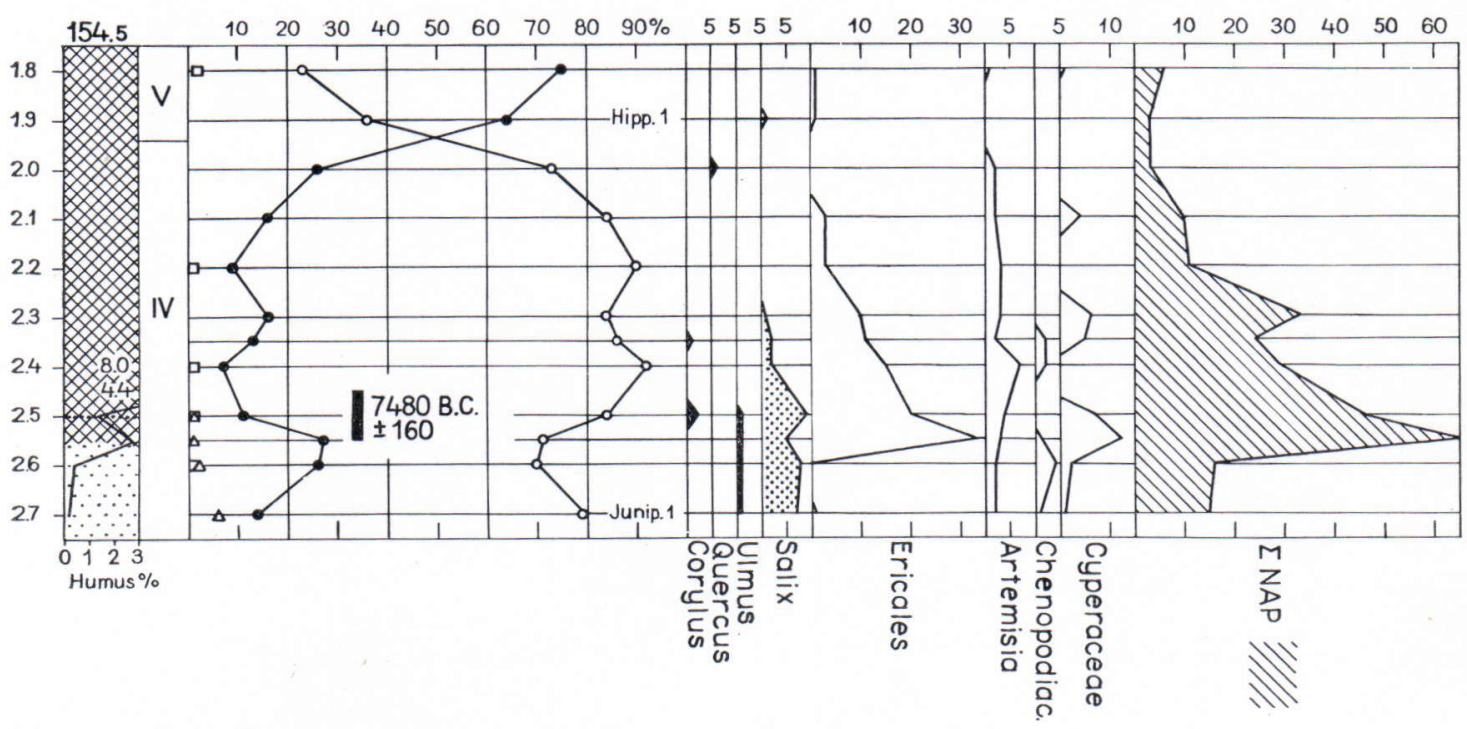

Fig. 16. Pollen diagram of the Mäkilampi bog. Hipp. = Hippophaë, Junip. = Juniperus. 


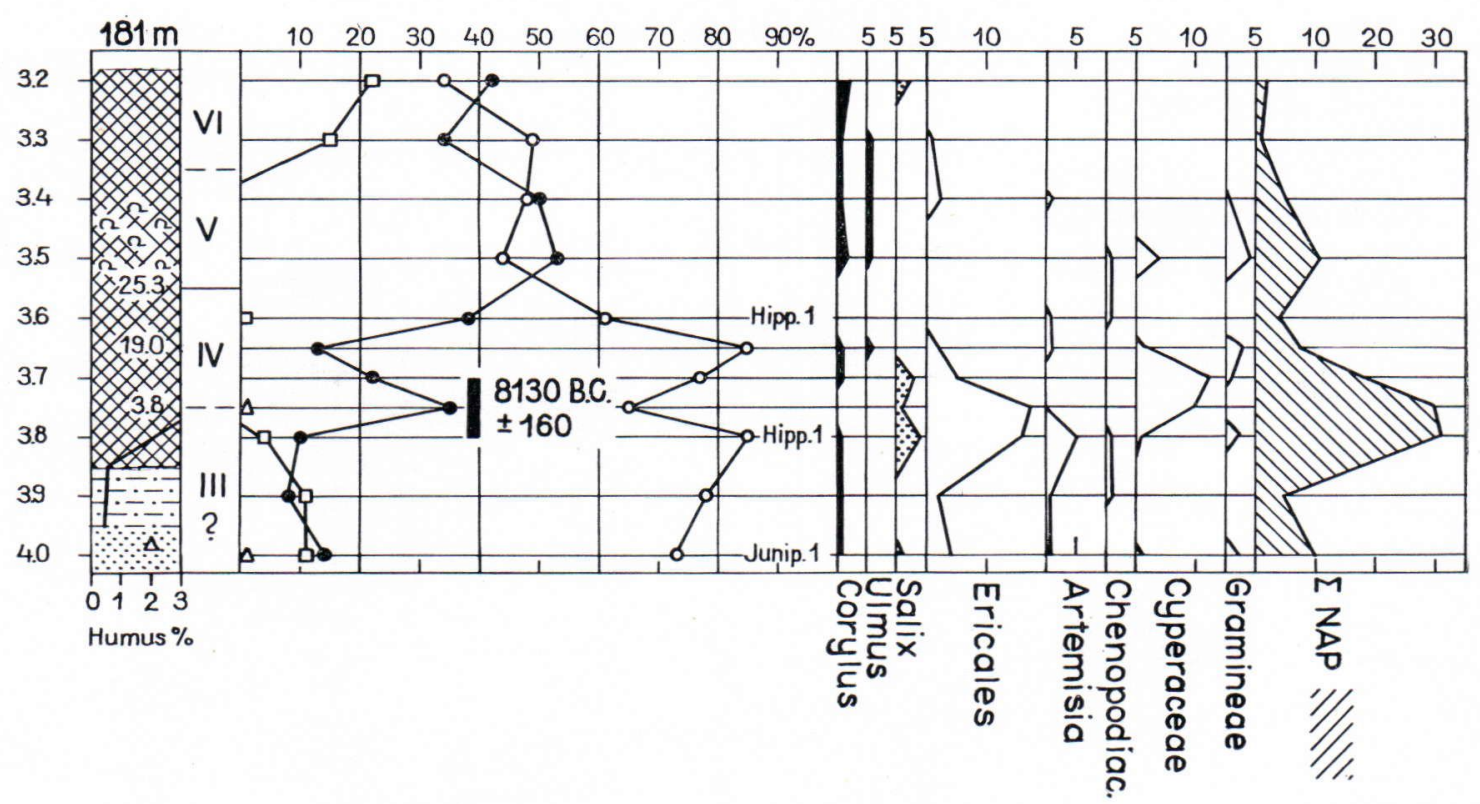

Fig. 17. Pollen diagram of the Vuorilampi bog.

ments of the Lintulampi bog in the Tampere area. Calving and formation of bays along the ice-margin also occurred in the area of the Päijänne basin as already concluded by Sauramo (1923).

A Betula maximum and a considerable NAPflora, with a maximum value of $30 / 100 \mathrm{AP}$, is typical of the pollen composition in the bottom sediments from Vuorilampi. It is comparable with the pollen flora of the clay beds associated with the Jyväskylä ice-marginal formation (Repo 1964). It differs from the typical flora of the Younger Dryas period by the lack of a distinct NAP-maximum. With this in mind, the reliability of the $\mathrm{C}^{14}$-dating due to possible contamination by an interglacial organic component is questionable. This possibility is also strengthened by the results of the diatom analyses (Table 1).

There are relatively abundant worn fresh water diatoms (Pinnularia fragm. $80 \%$ ) in the lower part of the dated bottom sediment containing biogenic matter but none in the upper part. The central part contains 2 forms of Melosira islandica. In the silt below the muddy layer, $14 \%$ of salt and brackish water species were counted. The same species have been encountered in interglacial sediments. Starting with the most abundant, the species are as follows: Coscinodiscus excentricus, Grammatophora oceanica, Rhabdonema arcuatum, Stephanopyxis sp. fragm. and a Coscinodiscus velatus-type. Deeper down, however, these marine species are missing.

Since the basin is located at a considerably higher elevation than is generally attributed to the Yoldia stage (Sauramo 1958: 155 m, Hyyppä 1963: $160 \mathrm{~m}$ ), these previous results concerning the Yoldia level must be erroneous, or it is a question of the redeposition of interglacial diatoms. No special investigation of ancient shorelines in the area was conducted by the authors, but it is evident that the highest shore-line here is considerably above the $160 \mathrm{~m}$ level. According to Ramsay (1958), the highest shore-line at Ronimäki (Ronninmäki) is at an elevation of $194 \mathrm{~m}$.

An early Preboreal biogenic sediment from the bog of Lapaneva in Kihniö, 130 kilometers west of Jyväskylä, was dated by Salmi (1962) at a $\mathrm{C}^{14}$-age of $9850 \pm 320 \mathrm{~B}$. P.. This bog basin is 
TABLE 1.

\begin{tabular}{|c|c|c|c|c|c|c|}
\hline \multirow{2}{*}{$\begin{array}{l}\mathrm{s}=\text { salt- and brackish-water forms } \\
\mathrm{f}=\text { fresh-water forms } \\
\mathrm{f}^{+}=\text {big lake-forms }\end{array}$} & \multicolumn{6}{|c|}{ Vuorilampi } \\
\hline & 365 & 370 & 375 & 380 & 390 & $400 \mathrm{~cm}$ \\
\hline 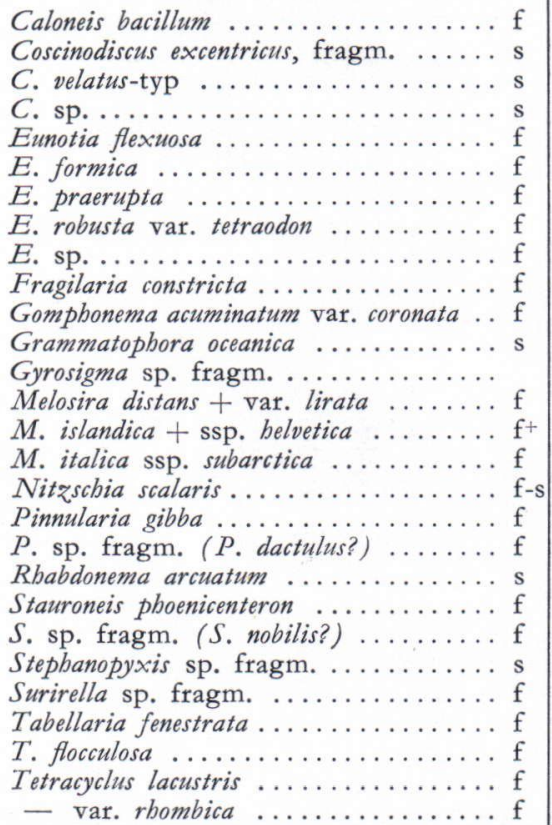 & $\begin{array}{l}= \\
= \\
= \\
= \\
= \\
= \\
= \\
= \\
= \\
= \\
= \\
= \\
= \\
= \\
= \\
= \\
=\end{array}$ & $\begin{array}{l}= \\
= \\
= \\
= \\
= \\
= \\
= \\
= \\
= \\
= \\
= \\
= \\
= \\
= \\
=\end{array}$ & 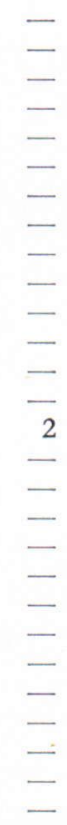 & 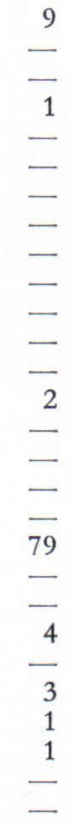 & $\begin{array}{r}-4 \\
1 \\
- \\
- \\
- \\
1 \\
- \\
- \\
3 \\
1 \\
24 \\
23 \\
4 \\
1 \\
7 \\
1 \\
1 \\
1 \\
- \\
- \\
-\end{array}$ & $\begin{array}{r}- \\
- \\
- \\
1 \\
6 \\
1 \\
1 \\
1 \\
1 \\
1 \\
5 \\
10 \\
13 \\
13 \\
2 \\
- \\
- \\
- \\
- \\
- \\
1 \\
1 \\
2\end{array}$ \\
\hline & - & - & 2 & 100 & 72 & 59 \\
\hline
\end{tabular}

in relation to the Näsijärvi (Virkkala 1963) - Jyväskylä ice-marginal formation located farther north than Vuorilampi. Thus, both dates agree and support the conception that the biogenic sediment in the Vuorilampi bog is of primary origin. According to the $\mathrm{C}^{14}$-determination, the ice-margin would have retreated past the Jyväskylä area around $8160 \pm 160$ B. C.. According to Hyyppä (1963), the ice-margin departed from the 3rd Salpausselkä in 8213 B. C.. If the retreat of the ice-margin from the 3rd Salpausselkä to the Näsijärvi-Jyväskylä ice-marginal formation could be assumed to have required a span of some $200 \mathrm{yrs}$, this would imply a mean annual rate of retreat of 0.5 kilometers along the Tampere-line. This same value was given by Sauramo (1940) as the maximum rate of retreat in lower Satakunta in southwestern Finland. In accordance with the above calculations, the rate of retreat was even greater in the region of the Päijänne-basin where a deep embayment was formed in the ice sheet. The highest region around Jyväskylä could have become free of ice at an early stage. More exact dating of the deglaciation would require additional pollen analyses and $\mathrm{C}^{\mathbf{1 4}}$-datings of the early biogenic sediments and studies of varved clays. The present results of the $\mathrm{C}^{14}$-determinations are fairly close to the generally accepted dating of the retreat of the continental ice-sheet in Scandinavia.

Acknowledgements - The authors want to express their gratitude for the financial aid given them by the Emil Aaltonen Foundation, making this study possible. 


\section{REFERENCES}

AARIO, R. (1965) Development of ancient Lake Päijänne. Ann. Acad. Sci. Ser. Fennicae A, 81.

Aartolahtr, T. (1966) Koijärven-Urjalan drumliinikenttä. Summary: The Koijärvi-Urjala Drumlin Field. Terra Nr. 2/1966.

- (1968) Die Geomorphologie des Gebiets von Tammela, Südfinnland. Fennia 97.

Alden, W. C. (1905) The Drumlins of Southeastern Wisconsin. Bull. of the Geol. Surv. 57.

- (1918) The Quaternary geology of southeastern Wisconsin, with a chapter on the older rock formations: U.S. Geol. Survey Prof. Paper 106.

Apuhtin, N. I. \& I. I. Krasnoff (1967)

Апухтин, Н. И. \& И. И. Краснов (1967) Геология четвертичных отложений Северо-Запада европейской части СССР. - Издательство »НЕДРА«. Ленинград.

Benre, K. (1967) The Late Glacial and Early Postglacial history of vegetation and climate in Northwestern Germany. Review of Paleobotany and Palynology.

Brander, G. (1934) Beskrivning till jordartskartan C 3, Kuopio. Résumé en français. General Geological Map of Finland.

Chamberlin, T. C. (1894) Proposed genetic classification of Pleistocene glacial formations. Jour. Geology, v. 2.

Donner, J. J. (1969) Land/sea level changes in southern Finland during the formation of the Salpausselkä endmoraines. Bull. Geol. Soc. Finland 41.

Ebers, Edith (1926) Die bisherigen Ergebnisse der Drumlinforschung. N. Jb. Min., Beil.bd. B 53.

FAIRChILD, H. L. (1907) Drumlins of central-western New York. N.Y. State Museum, Bull. 111.

FLINT, R. F. (1949) Glacial geology and the Pleistocene epoch. New York.

Fogelber G, P. (1970) Geomorphology and deglaciation at the Second Salpausselkä between Vääksy and Vierumäki, Southern Finland. Comm. Phys.-Math. Vol. 39.

Frosterus, Benj. (1902) Beskrifning till bergartskartan C 2, S:t Michel. Résumé en français. General Geological Map of Finland.

- (1911) Beskrifning till jordartskartan C 2, S:t Michel. Résumé en français. Ibid.

GilberG, G. (1955) Den glaciala utvecklingen inomSydsvenska höglandets västra randzon. I. Glacial erosion och moränackumulation. G.F.F. 77.

HellaAkoski, A. (1922) Suursaimaa. Referat: GrossSaimaa. Fennia 43.

- (1928) Puulan järviryhmän kehityshistoria. Referat: Die Entwicklungsgeschichte der Puula-Seengruppe. Fennia 51.
Hillefors, A. (1969) Väst-Sveriges glaciala historia och morfologi. The glacial history and morphology of West-Sweden. L.U.G.I. Avh. 60.

Hoppe, G. (1948) Isrecessionen från Norrbottens kustland i belysning av de glaciala formelementen. Geographica 20 .

- (1951) Drumlins i nordöstra Norrbotten. Geogr. Ann. 33.

- (1952) Hummocky Moraine Regions, with Special Reference to the Interior of Norrbotten. Ibid. 34.

Нyүррӓ, E. (1954) Åsarnas uppkomst. Geologi Nr. 5/1954.

- (1963) On the late-Quaternary history of the Baltic Sea. Fennia 89.

HänNINEN, K. (1915) Drumlinimaisemien järvistä ja reiteistä Oulankajoen alueella. Referat: Über die Seenketten der Drumlinlandschften im Gebiet des Flusses Oulankajoki Kirchspiel Kuusamo (Finnland). Maant. yhd. julk. 11.

Härme, M. (1961) On the shear zones and fault lines in Finnish pre-cambrian strata. Fennia 89.

JAATINEN, S. (1952) Ramsholm - en åländsk drumlin. Terra Nr. 2/1952.

JALAS, J. and V. OKKo (1951) Botanical and geological analysis of the Cladium Mariscus station in Joroinen. Vanamo 5:2.

Kалкко, Jон. (1932) Streifigkeit der Landschaft in Ladoga-Karelien mit besonderer Berücksichtigung ihrer Abhängigkeit vom Felsuntergrund. Fennia 58.

Kujansuu, R. (1967) On the deglaciation of western Finish Lapland. Bull. Comm. géol. Finlande 232.

Lappalainen, V. (1962) The shore-line displacement on southern Lake Saimaa. Acta Bot. Fenn. 64.

Lerviskä, I. (1928) Über die Ose Mittelfinnlands. Fennia 51.

- (1951) Drei esizeitliche Randmoränen. Ibid. 74.

Lundevist, J. (1969) Problems of the so-called Rogen moraine. S.G.U., C 648.

Magnusson, N. H., G. Lundevist \& E. Granlund (1949) Sveriges geologi. Stockholm.

Mölder, K. \& M. SALMI (1954) Maalajikartan selitys, Lehti B 3, Vaasa. Suomen geoliginen yleiskartta.

Mölder, K., V. Valovirta \& K. Virkkala (1957) Über Spätglazialzeit in Südfinnland. Bull. Comm. géol. Finlande 178.

Nilsson, E. (1968) Södra Sveriges senkvartära historia. The late-Quaternary history of Southern Sweden. K.V.A. Handl. 12: 1.

Okxo, Marjatta (1962) On the Development of the First Salpausselkä, West of Lahti. Bull. Comm. géol. Finlande 202. 
Oкко, Marjatta (1965) M. Sauramo's Baltic Ice Lake B IV-B V-B VI; re-evaluation. Ann. Acad. Sci. Fennicae, Ser. A. III. Geol.-Geogr. 84.

Oкко, V. (1945) Untersuchungen über den Mikkeli-Os. Fennia 69.

- (1949) Explanation to the map of surficial deposits B 4, Kokkola. Geological Map of Finland.

RAMsAY, W. (1895) Till frågan om senglaciala hafvets utbredning i södra Finland. Fennia 12.

Repo, R. (1964) Observations on the Jyväskylä Ice-Marginal Formation in Central Finland. Bull. Comm. géol. Finlande 215.

Repo, R. \& R. Tynni (1967) Zur spät- und postglazialen Entwicklung im Ostteil des Ersten Salpausselkä. C.R. Soc. Géol. Finlande 39.

- (1969) Morphologisch-stratigraphische Grundzüge des otslichen Salpausselkä-Gebiets. Bull. Geol. Finland 41.

Russell, I. C. (1895) The influence of debris on the flow of glaciers. Jour. geol., vol. 3.

SAARnistro, M. (1970) The Late Weichselian and Flandrian history of the Saimaa Lake Complex. Comm. Phys.Math. Vol 37.

SAKSELA, M. (1930) Geologisen kehityksen vaikutuksesta maalajipeitteeseen, maanviljelykseen ja asutukseen Jyväskylän ympäristössä. Referat: Über den Einfluss der geologischen Entwicklung auf die Oberflächenbildungen, den Ackerbau und die Besiedelung in der Umgebung der Stadt Jyväskylä (Finnlan). Fennia 52.

SALMI, M. (1962) Radiocarbon determinations from the bog profile of Lapaneva, Kihniö, western Finland. Bull. Comm. géol. Finlande 204.

Sauramo, M. (1923) Studies on the Quaternary Varve Sediments in Southern Finland. Bull. Comm. géol. Finlande 60 .

- (1926) Maalajikartan selitys D 2, Kajaani. Geological Map of Finland.

- (1929) The Quaternary Geology of Finland. Bull. Comm. géol. Finlande 89.

- (1940) Suomen luonnon kehitys jääkaudesta nykyaikaan. Porvoo-Helsinki.

- (1958) Die Geschichte der Ostsee. Ann. Acad. Scient. Fennicae, Ser. A, III, 51.
Sederholm, J. (1889) Om istidens bildningar i det inre af Finland. Fennia 7.

Simonen, A. (1960) Pre-Quaternary rocks in Finland. Ibid. 191.

Smalley, I. J. \% D. J. Unwin (1968) The formation and shape of drumlins and their distribution and orientation in drumlin field. Journ. Glaciol. 7.

Synge, F. M. (1952) Retreat stages of the last ice-sheet in the British Isles. Irish Geography 2, 4.

TANner, V. (1915) Studier öfver kvartärsystemet i Fennoscandias nordliga delar. III. Om landisens rörelser och afsmältning i finska Lappland och angränsande trakter. Résumé en français. Fennia 36.

Tynni, Rrsto (1970) Piilevät v. 1969 sataneessa punertavassa lumessa. Summary: Diatoms from a dust stained snowfall in 1969. Geolkgi N:o 5-6.

Valovirta, V. (1962) Cladium mariscus in Finnland während der Postglazialzeit. Bull. Comm. géol. Finlande 197.

VirkKalA, K. (1949) Explanation to the map of superficial deposits D 4, Nurmes. Geological Map of Finland.

- (1951) Glacial geology of the Suomussalmi area, East Finland. Bull. Comm. géol. Finlande 155.

- (1959) Maaperäkartan selitys 2043, Kerava. Geological Map of Finland.

- (1960) Explanation to the map of superficial deposits 4421, 4422, 4423 - 4441, 4424, Hyrynsalmi, Suomussalmi, Vuokkijärvi, Raate. Ibid.

- (1963) On Ice-Marginal Features in Southwestern Finland. Bull. Comm. géol. Finlande 210.

- (1969) Maaperäkartan selitys, lehti 2131, Hämeenlinna. Explanation to the map of Quaternary deposits. Geological Map of Finland.

Wegmann, C. E. (1928) Über die Tektonik der jüngeren Faltung in Ostfinnland. Fennia 50.

Woldstedt, P. (1954) Das Eiszeitalter. Stuttgart.

Zoller, H. (1960) Pollenanalytische Untersuchungen zur Vegetationsgeschichte der insubrischen Schweiz. Denkschr. Schweiz. Naturforsch. Ges., Bd. 83, Abh. 2.

Manuscript received, January 20, 1971. 